\title{
Sustainability and factors affecting the success of community-based reproductive health programs in rural Northwest Ethiopia
}

\author{
Daniel Argaw, Mesganaw Fanthahun, Yemane Berbane
}

\begin{abstract}
Various Community-Based Reproductive Health interventions were initiated in many developing countries but their effectiveness has not been evaluated as much as needed. A comparative cross sectional study was carried out in February 2002 among women who participated in community based reproductive health interventions in South Gondar zone, Ethiopia. The study was conducted in eight kebeles taking successful and weak program areas for comparison. Both quantitative and qualitative methods were used for data collection. The qualitative method included key informants interview, and Focus Group Discussions with Community-based reproductive health agents (CBRHAs). A multistage sampling technique was employed to select 792 study subjects for the quantitative part of the study. Awareness of the presence of the CBRHA in the locality, participation in selection of the agents, acceptance of the agent, and evertalking to CBRHA about reproductive health issues were significantly higher in successful than in weak program areas $[\mathrm{OR}(95 \% \mathrm{CI})=2.32(1.74,3.08), 3.28(1.22,9.27), 6.65(3.59,12.43)$, and 5.05(3.22,7.96), respectively]. In multiple logistic regression analysis awareness of presence of CBRHA in the village, acceptance of the CBRHA, and having had discussion with CBRHA maintained significant associations with type of community-based reproductive health program (successful/weak). Focus Group Discussions and Key Informant Interviews revealed better involvement of community leaders and health workers in the process of selecting and supervising CBRHA in successful areas compared to weak areas. The sustainability score of the Community-Based Reproductive Health Program (CBRHP) graded by the program coordinators was 2.92 out of 5. Acceptance of the CBRHAs, communication of the agents with community members, level of support to the agents, better involvement of community representatives in the selection process were found to be the major factors affecting CBRHP. Overall sustainability of the CBRHP was low which calls for an urgent action. (Afr J Reprod Health 2007; 11[2]:70-79).
\end{abstract}

\section{RÉSumÉ}

Viabilité et facteurs qui affectent le succès des programmes de la santé de reproduction qui sont basés sur les communautés au nord-ouest rural de l'Ethiopie Les différentes interventions de la santé de reproduction qui sont basées sur les communautés ont été mises en place dans plusieurs pays en voie de développement mais leur efficacité n'a pas été suffisamment évaluée. Une étude transversale comparative a été menée au mois de février 2002 auprès des femmes qui ont participé aux interventions de la santé de reproduction dans la zone du sud Gondar en Ethiopie. L'étude a été menée dans huit kebeles, tout en comparant les domaines des programmes qui ont eu de succès et ceux qui sont faibles. Les données ont été recueillies à l'aide des méthodes quantitatives et qualitatives. La méthode qualitative a compris l'interview des principaux informateurs, les discussions à groupe cible avec les agents de la santé de reproduction qui sont basés dans la communauté (ASRBC). Nous avons selectionné 792 sujets d'étude pour la partie quantitative de l'étude à l'aide d'une technique d'échantillon à plusieurs étapes. La conscience de la présence des ASRBC dans la région, la participation dans la selection de l'agent, l'acceptation des agents et le fait de parler tout le temps avec les ASRBC concernant les questions de la santé de reproduction a été plus élevée dans les domaines des programmes qui ont réussi que dans les domaines des programmes faibles $[\mathrm{OR}(95 \% \mathrm{CI})=2,32(1,74,3,08), 3,28(1,22,9,27), 6,65(3,59,12,43)$ et $5,05(3,22,7,96)$ respectivement]. Dans l'analyse de la regression logistique multiple la conscience de la présence des ASRBC dans le village, l'acceptation des ASRBC et le fait d'avoir eu des discussions avec les ASRBC ont maintenu des associations importantes avec le genre de programme de la santé de reproduction qui est basé dans la communauté (réussi/faible). Les discussions à groupe cible et les interviews des principaux informateurs ont révelé qu'il y a une meilleure participation des dirigeants de la communauté et le personnel des services de la santé dans le procès de la selection et de la surveillance des ASRBC dans les domaines qui ont réussi par rapport aux domaines faibles. Le score de la viabilité du programme de la santé de reproduction qui est basé dans la Communauté (PSRBC) d'après les notes données par les coordinateurs était de 2, 92 sur 5. L'acceptation des PSRBC, la communication des agents avec les members de la communauté, le niveau de soutien accordé aux agents, la meilleure participation des représentants de la communauté au procès de la selection, selon les résultats de l'étude, constituaient les facteurs majeurs qui affectent la PSRBC. La viabilité d'ensemble du PSRBC était faible et exige ainsi une action urgente. (Rev Afr Santé Reprod 2007; 11[2]:70-79).

KEY WORDS: Community based reproductive health program; reproductive bealth service; reproductive bealth programme sustainability; community-based distribution;

Correspondence: Dr Daniel ArgawWHO/Ethiopia, P.O.Box 3069, Addis Ababa, Ethiopia.danie@@whoet.org or daniel7019@yahoo.com 


\section{Introduction}

The broad concept of reproductive health $(\mathrm{RH})$ was propagated intensively after the 1994 Cairo ICPD when governments ratified the Cairo programme of action, which focused on the delivery of a comprehensive, and client centred view of $\mathrm{RH}$ for the promotion of $\mathrm{RH}$ in addition to family planning ${ }^{(1)}$. The dimension of reproductive ill-health encompasses problems such as female genital mutilation (FGM), malnutrition, anaemia, abortion, reproductive tract infections (RTI) including sexually transmitted infections (STD) and HIV/AIDS, infertility, unregulated fertility, maternal morbidity \& mortality, sexual and gender violence and other related problems ${ }^{1,2}$. The World Health Development report of 1993 revealed that in women of reproductive age in developing countries, reproductive ill health accounts for $36 \%$ of the total disease burden as compared to $12 \%$ for $\mathrm{men}^{3}$.

The status of both general health and RH in Ethiopia is dismal even when compared to other developing countries. Ethiopia is the third most populous country in Africa with high population growth rate $(2.9 \%)$ and total fertility rate (5.9 child per woman $)^{4}$. As the primary health service coverage is quite low, the large proportion of the population do not have access to both general and reproductive health services. The maternal, infant and under-five mortality rates are one of the highest in the world. The country hosts $9 \%$ of the world estimated people living with HIV/ AIDS according to the 2000 UNAIDS country report $^{5}$.

The low level of access to conventional health care services and the magnitude of the problem call for an alternative service delivery strategy to reach the vast rural majority. This was one of the reasons to adopt CBRHP by the Ministry of Health $(\mathrm{MOH})$ to promote $\mathrm{RH}$ awareness and services particularly for rural areas. As in many parts of the world, CBRHPs have evolved from community based distribution (CBD) programs in Ethiopia. There are evidences that showed CBD family planning programs are cost-effective and alternative options to institution-based service delivery in many developing countries including Ethiopia ${ }^{6,7,8}$.

This study looked into a CBRHP in two districts of a region in the northwest part of the country. The program was implemented by the public health sector in collaboration with the German Technical Cooperation agency (GTZ) ? A number of CBRHAs were trained and deployed to rural project areas. These agents provide RH services including education to the community they serve. There was a significant increase in contraceptive prevalence rate (CPR) during the initial project implementation period in almost all project areas. It was difficult to sustain the good achievements in most places as time progressed. The reports of the regional health bureau and the project office depict that there was significant difference among the various intervention areas in the growth of CPR, functionality of the agents, integration of program components and overall program viability. Challenges such as high number of drop outs of CBRHAs, defaulting clients, low motivation or involvement of supervising health workers were reported as major problems ${ }^{8,10}$.

Therefore, this study was conducted to assess sustainability and determine the factors that cause variations in the success of CBRHP.

\section{Materials and Methods}

The study used quantitative and qualitative methodology. The quantitative part was a comparative cross-sectional survey carried out in 8 rural kebeles (lowest administrative units) of South Gondar Administrative Zone of Amhara Region between January and February 2002. The comparison was made between "successful" and "weak" programme areas to assess factors affecting the success and sustainability of community based reproductive health programs. The criteria used for selecting study areas or 
groups were CPR and proportion of active CBRHAs. The study population were women of reproductive age groups ( $15-49$ years). The sample size was determined using the formula for comparing two proportions with 95\% confidence level and 90\% power. A multistage sampling was used to select 792 study subjects from the two districts. In each district four kebeles were selected by simple random sampling method. Each kebele has a population of about 5000 people. The number of households in each kebele was determined using proportion allocation method according to population size. Finally the study units, women of reproductive age groups, were selected by systematic random sampling method. In case there was more than one eligible in one household, only one was selected by lottery method. A pretested questionnaire was administered to the selected women by trained interviewers who completed grade 12. Data were collected on socio-demographic, reproductive characteristics, knowledge, attitude, and practice of respondents concerning family planning and the community based reproductive services. Data were entered into a computer and statistical analysis was done using EPI info and SPSS statistical software.

The Qualitative part of the study included key informants interviews with program coordinators at various levels and focus group discussions with CBRHAs in both "successful" and "weak" areas moderated by the principal investigator and tape-recorded. Both the interviews \& FGDs were conducted using semistructured guides (questions). The discussions were then transcribed, summarized and analyzed. Program sustainability was assessed by asking program coordinators both in the government health offices and GTZ office to score separately factors of sustainability, which was developed by East African Investment group for Family Planning and RH programs in Ethiopia. According to this program sustainability assessment tool, organizational level factors constituted $60 \%$ of the scores, whereas service/community level factors comprised the rest $40 \%$ of the scores ${ }^{(11) .}$

\section{Operational Definitions}

Successful CBRHP- A program area which has achieved a CPR of $15 \%$ or more and has reasonable (low) attrition rate of CBRHAs, i.e., below $40 \%$.

Weak (Unsuccessful) CBRHP- A program area with CPR below 8\% two to three years after the introduction of a CBRH service in the area and has high attrition rate of the CBRHA, i.e., above $70 \%$.

CBRH Service Use- Getting or receiving any one of the services from a CBRHA among the range of services to be provided by CBRHAs. NB: Only program areas (districts and kebeles) that fulfil both the selection criteria are included in the study.

\section{Results}

A total of 792 women, 396 in each program area were interviewed. The comparison groups showed no statistically significant difference in their socio-demographic and reproductive characteristics except on literacy status where higher proportion of respondents in the successful program areas were literate. However, the great majority of respondents in both the study areas were illiterate (Table 1).

Table 2 shows the knowledge, attitude, and practice of the study population with respect to community based reproductive health services. Most respondents, $61.1 \%$, in the successful program areas know the presence of a CBRHA in their village as compared to $40.4 \%$ in the weak program areas. This difference was statistically significant $[\mathrm{OR}=2.3295 \% \mathrm{CI}(1.74,3.08)]$. The participation of the communities in the selection process of the CBRHA was found to be low in both areas, $4.8 \%$ and $1.52 \%$ in successful and weak program areas respectively. However, the

African Journal of Reproductive Health Vol. 11 No.2 August 2007 
Table 1: Socio-demographic characteristics of women of reproductive age groups in successful and weak/failed CBRHP areas, South Gondar, Ethiopia, February 2002

\begin{tabular}{|c|c|c|c|c|}
\hline Variable & $\begin{array}{l}\text { Successful CBRHP } \\
\text { Areas N(\%) }\end{array}$ & $\begin{array}{l}\text { Weak CBRHP } \\
\text { Areas N(\%) }\end{array}$ & $\chi^{2}$ & p-value \\
\hline $\begin{array}{l}\text { 1. Age } \\
\begin{array}{l}15-19 \text { years } \\
20-24 \\
25-29 \\
30-34 \\
35-39 \\
40+ \\
\text { Mean } \pm \text { SD }\end{array}\end{array}$ & $\begin{array}{l}\mathrm{N}=396(100) \\
51(12.9) \\
81(20.5) \\
85(21.5) \\
63(15.9) \\
61(15.4) \\
55(13.9) \\
28.43 \pm 8\end{array}$ & $\begin{array}{l}\mathrm{N}=396(100) \\
76(19.2) \\
73(18.4) \\
94(23.7) \\
66(16.7) \\
51(12.9) \\
36(9.1) \\
27.13 \pm 7.73\end{array}$ & 10.72 & 0.057 \\
\hline $\begin{array}{l}\text { 2. Marital Status } \\
\text { Married } \\
\text { * Single }\end{array}$ & $\begin{array}{l}358(90.4) \\
38(9.6)\end{array}$ & $\begin{array}{l}336(84.8) \\
60(15.2)\end{array}$ & 7.4 & 0.06 \\
\hline $\begin{array}{l}\text { 3. Religion } \\
\text { Orthodox } \\
\text { Muslim }\end{array}$ & $\begin{array}{l}393(99.2) \\
3(0.8)\end{array}$ & $\begin{array}{l}394(99.5) \\
2(0.5)\end{array}$ & 0.2 & 0.65 \\
\hline $\begin{array}{l}\text { 4. Education } \\
\text { Illiterate } \\
\text { Read \& write } \\
\text { Formal Education } \\
\text { (Grade } 2-8 \text { ) }\end{array}$ & $\begin{array}{l}308(77.8) \\
47(11.9) \\
41(10.4)\end{array}$ & $\begin{array}{l}316(79.8) \\
64(16.2) \\
16(4.0)\end{array}$ & 13.67 & 0.01 \\
\hline $\begin{array}{l}\text { 5. Occupation } \\
\text { Farmers } \\
\text { Housewives } \\
\text { **Others }\end{array}$ & $\begin{array}{l}60(15.2) \\
319(80.6) \\
17(4.2)\end{array}$ & $\begin{array}{l}49(12.4) \\
322(81.3) \\
25(6.3)\end{array}$ & 3.83 & 0.43 \\
\hline
\end{tabular}

* Single includes divorced, widowed, and never married;

**Others include local drink sellers, students, crafts women etc.

chance of participating in the selection process was significantly higher for the successful areas $[\mathrm{OR}(95 \% \mathrm{CI})=3.28(1.22,9.27)]$. Likewise, acceptance of the CBRHA, $79.1 \%$ Vs. $51.6 \%$, and ever talking with the CBRHA about family planning or reproductive health, $48.9 \%$ vs $18.9 \%$ were found to be significantly better in successful areas $[\mathrm{OR}=6.6595 \% \mathrm{CI}(3.59,12.43), \mathrm{OR}=5.05$ $95 \%$ CI $(3.22,7.96)$ respectively]. In multiple logistic regression analysis awareness of presence of CBRHA in the village, acceptance of the CBRHA, and having had discussion with CBRHA maintained significant associations with type of community based reproductive health program (successful/weak).

African Journal of Reproductive Health Vol. 11 No.2 August, 2007
Concerning payment to the CBRHAs for the service they are providing, $36.6 \%$ of study subjects in successful and $28.5 \%$ in weak program areas agreed that the community should pay for the services offered by the agents[OR $(95 \% \mathrm{CI})=$ $1.44(1.05,1.96)]$. In addition, significantly better associations with successful program areas were found with the likelihood of being willing to work as a CBRHA if selected by the community $[\mathrm{OR}(95 \% \mathrm{CI})=1.82(1.29,2.57)]$ and satisfaction of the study women by the CBRHS [OR $(95 \% \mathrm{CI})$ $=6.98(4.86,10.03)]$ although these significant associations were not maintained in multiple regression analysis. 
74 African Journal of Reproductive Health

Table 2: Comparison of knowledge, attitude and practice of women on community based reproductive health services in successful and weak CBRHP areas, South Gondar, February 2002

\begin{tabular}{|c|c|c|c|c|c|}
\hline Variable & $\begin{array}{l}\text { Successful } \\
\text { CBRHP areas } \\
\mathrm{N}(\%) \\
\mathrm{N}=396\end{array}$ & $\begin{array}{l}\text { Weak CBRHP } \\
\text { areas } \mathrm{N}(\%) \\
\mathrm{N}=396\end{array}$ & OR & $(95 \% \mathrm{CI})^{*}$ & OR $(95 \% \mathrm{CI})$ \\
\hline \multicolumn{6}{|l|}{$\begin{array}{l}\text { Awareness of the presence of } \\
\text { CBRHA in the village }\end{array}$} \\
\hline $\begin{array}{l}\text { Yes } \\
\text { No }\end{array}$ & $\begin{array}{l}242(61.1) \\
154(38.9)\end{array}$ & $\begin{array}{l}160(40.4) \\
236(59.6)\end{array}$ & $\begin{array}{l}2.32 \\
1 * *\end{array}$ & $(1.74,3.08)$ & $1.4(1.2,1.9)$ \\
\hline \multicolumn{6}{|l|}{$\begin{array}{l}\text { Participation in selection of } \\
\text { CBRHA }\end{array}$} \\
\hline $\begin{array}{l}\text { Yes } \\
\text { No }\end{array}$ & $\begin{array}{l}19(4.80) \\
377(95.20)\end{array}$ & $\begin{array}{l}6(1.52) \\
390(98.48)\end{array}$ & $\begin{array}{l}3.28 \\
1 * *\end{array}$ & $(1.22,9.27)$ & $1.22(0.42,3.52)$ \\
\hline $\begin{array}{l}\text { Acceptance of the CBRHA } \\
\text { Accepted } \\
\text { Not accepted }\end{array}$ & $\begin{array}{l}\mathrm{N}=208^{1} \\
188(90.38) \\
20(9.62)\end{array}$ & $\begin{array}{l}\mathrm{N}=138^{1} \\
82(59.42) \\
56(40.58)\end{array}$ & $\begin{array}{l}6.65 \\
1 * *\end{array}$ & $(3.59,12.43)$ & $4.6(2.5,8.4)$ \\
\hline $\begin{array}{l}\text { Ever talked with the CBRHA } \\
\text { Yes } \\
\text { No }\end{array}$ & $\begin{array}{l}118(29.80) \\
278(70.20)\end{array}$ & $\begin{array}{l}31(7.83) \\
365(92.17)\end{array}$ & $\begin{array}{l}5.05 \\
1 * *\end{array}$ & $(3.22,7.96)$ & $3.5(2.1,6.0)$ \\
\hline \multicolumn{6}{|l|}{$\begin{array}{l}\text { Should the community pay to } \\
\text { CBRHA for the service they } \\
\text { provide }\end{array}$} \\
\hline $\begin{array}{l}\text { Yes } \\
\text { No } \\
\text { I don't know }\end{array}$ & $\begin{array}{l}145(36.6) \\
243(61.4) \\
8(2 \%)\end{array}$ & $\begin{array}{l}113(28.5) \\
272(68.7) \\
11(2.8)\end{array}$ & $\begin{array}{l}1.44 \\
1 * * \\
0.84\end{array}$ & $\begin{array}{l}(\mathbf{1 . 0 5 , 1 . 9 6 )}) \\
(0.30,2.29)\end{array}$ & $\begin{array}{l}\mathbf{2 . 1}(\mathbf{1 . 2}, \mathbf{3 . 9}) \\
3.5(0.15,82.1)\end{array}$ \\
\hline \multicolumn{6}{|l|}{$\begin{array}{l}\text { Willingness to work as } \\
\text { CBRHA if selected by } \\
\text { the Community }\end{array}$} \\
\hline $\begin{array}{l}\text { Willing } \\
\text { Not willing } \\
\text { Uncertain }\end{array}$ & $\begin{array}{l}123(31.1) \\
256(64.6) \\
17(4.3)\end{array}$ & $\begin{array}{l}78(19.7) \\
296(74.7) \\
22(5.6)\end{array}$ & $\begin{array}{l}1.82 \\
1 * * \\
0.89\end{array}$ & $\begin{array}{l}(1.29,2.57) \\
(0.44,1.80)\end{array}$ & $\begin{array}{l}1.5(0.89,2.63) \\
0.43(0.07,2.51)\end{array}$ \\
\hline $\begin{array}{l}\text { Satisfaction with CBRHS } \\
\text { Satisfied } \\
\text { Not satisfied } \\
\text { Can't comment }\end{array}$ & $\begin{array}{l}213(53.8) \\
104(26.3) \\
79(19.9)\end{array}$ & $\begin{array}{l}76(19.2) \\
259(65.4) \\
61(15.4)\end{array}$ & $\begin{array}{l}6.98 \\
1 * * \\
3.23\end{array}$ & $\begin{array}{l}(4.86,10.03) \\
(2.11,4.93)\end{array}$ & $\begin{array}{l}1.93(0.47,7.95) \\
1.09(0.33,3.56)\end{array}$ \\
\hline $\begin{array}{l}\text { Affordability of service fee } \\
\text { requested by CBRHA } \\
\text { Affordable/fair } \\
\text { Not affordable/expensive } \\
\text { I don't know }\end{array}$ & $\begin{array}{l}204(51.52) \\
178(44.95) \\
14(3.53)\end{array}$ & $\begin{array}{l}184(46.47) \\
200(50.50) \\
12(3.03)\end{array}$ & $\begin{array}{l}1.25 \\
1 * * \\
1.31\end{array}$ & $\begin{array}{l}(0.93,1.67) \\
(0.55,3.12)\end{array}$ & \\
\hline \multicolumn{6}{|l|}{$\begin{array}{l}\text { Knowledge of a VHC that } \\
\text { monitors CBRHA activities } \\
\text { in the village }\end{array}$} \\
\hline $\begin{array}{l}\text { Yes } \\
\text { No } \\
\text { I don't know }\end{array}$ & $\begin{array}{l}225(56.8) \\
105(26.5) \\
66(16.7)\end{array}$ & $\begin{array}{l}84(21.2) \\
222(56.1) \\
90(22.7)\end{array}$ & $\begin{array}{l}5.66 \\
1 * * \\
1.55\end{array}$ & $\begin{array}{l}(3.97,8.09) \\
(1.03,2.34)\end{array}$ & $\begin{array}{l}1.36(0.34,5.22) \\
1.14(0.37,3.56)\end{array}$ \\
\hline
\end{tabular}

* Significant associations in bold

** Referent categories 
In successful areas about $57 \%$ of the respondents knew about the existence of village health committees that monitor the activities of CBRHAs, whereas only $21.2 \%$ of the respondents in weak performing areas knew about it. The difference was statistically significant in bivariate analysis $[(\mathrm{OR}(95 \% \mathrm{CI})=5.7(4.0,8.1)]$ The key informants interview with program coordinators at all level illustrated that the CBRHP has contributed to improved access of basic RH services to the community, improved awareness of the community to RH concepts particularly family planning, improved CPR (family planning) coverage in the region, establishing a link between the conventional health care system and enabled the sector to learn about the process of community participation. The program coordinators also expressed the challenges faced while implementing the program. The most common problems encountered were inadequate follow up and supervision of agents by health workers due to shortage of health personnel, budget and other constraints. Failure to strictly adhere to the selection criteria, high level of attrition of the agents due to absence or low incentives, and supply related problems were reiterated in all places. In the opinion of the program coordinators, the sustainability of the program largely depends on the continuity of the government or donor support to the program, provision of adequate and continuous supply of contraceptives and other materials, commitment of health workers and CBRHAs, and strong community and local leaders support and involvement.

Program sustainability assessment by program coordinators of the GTZ and government health offices indicated a low degree of sustainability ( $<3.0$ out of 5 ), which needs urgent actions to maintain the Program's sustainability (Table 3 ).

Table 3: Scoring for factors of sustainability by Program coordinators at regional, zonal, Woreda (District), and GTZ offices

\begin{tabular}{|c|c|c|c|}
\hline $\begin{array}{l}\text { Factors of Sustainability } \\
\text { (1) }\end{array}$ & $\begin{array}{l}\text { Ave. Score } \\
\text { (1 to 5) } \\
(2)\end{array}$ & $\begin{array}{l}\text { Weight } \\
\text { (3) }\end{array}$ & $\begin{array}{l}\text { Total Score } \\
(4)=(2) *(3)\end{array}$ \\
\hline Organizational level & 4 & 60 & 48 \\
\hline . Relationship with government & 3 & 12 & 24 \\
\hline Organizational system & 3 & 8 & 18 \\
\hline Management systems \& procedures & 3 & 6 & 36 \\
\hline Human resources & 3 & 12 & 18 \\
\hline Financial management & 3 & 6 & 18 \\
\hline Income sources & 3 & 6 & 18 \\
\hline Strategic planning & 3 & 6 & 12 \\
\hline Operations Research capability & & 4 & \\
\hline \multicolumn{2}{|l|}{ Service/Community level } & 40 & 10 \\
\hline . $\quad$ IEC: Demand generation \& maintenance & 2 & 5 & 15 \\
\hline Community participation & 3 & 5 & 15 \\
\hline Contraceptive logistics & 2 & 5 & 8 \\
\hline Existing services-Quality & 2 & 4 & 12 \\
\hline Existing services-Accessibility & 3 & 4 & 12 \\
\hline Existing services-Acceptability & 3 & 4 & 8 \\
\hline Existing services-Range/mix & 2 & 4 & 8 \\
\hline Existing services-counselling & 2 & 4 & 15 \\
\hline Scope for Diversification & 3 & 5 & \\
\hline \multicolumn{3}{|l|}{ Total } & 295 \\
\hline \multicolumn{3}{|l|}{ Divide by 100 to obtain score on a scale of 1 to 5} & 2.95 \\
\hline
\end{tabular}


The discussion with supervising health workers revealed that supervision and follow up was carried out in two ways; by going to CBRHAs working sites or by holding monthly meetings at the health facility where the agents come for reporting and collecting supplies. It was learnt that field supervision was conducted rarely in weak program areas while in the successful program areas it was done by integrating with other outreach health programs. The results of Focus Group Discussion (FGD) with currently active CBRHAs of both program areas are summarized under the various themes in Table 4. Virtually no mechanisms of supervision existed for weak program area CBRHAs, whereas monthly meetings were conducted with CBRHAs of the successful areas. Community involvement was generally considered not optimal, but was better in successful areas as witnessed in the selection of CBRHAs. Most agents answered that the community members were mostly unwilling to pay for the services. Rumours about side effects of "Pills", unavailability of injectables, lack of incentives for agents and negative attitude by men were also pointed out as challenges to the CBRHP.

\section{Disscusion}

This study employed both qualitative and quantitative methods giving the advantages of both methods to the findings. It indicated that acceptance of CBRHAs, awareness of the presence of the CBRHA in the locality, ever talking to CBRHA about reproductive health issues are important contributors of sustainability.

A higher proportion of study subjects $(79.1 \%)$ in successful areas have accepted the agents as compared to $(51.6 \%)$ weak program areas. The level of community participation, though low in both program areas, was relatively better in the successful program areas. The low acceptance of the agents in the weak program areas is perhaps mainly due to the low community leaders (community) involvement in the selection process. Various studies also have demonstrated that acceptance of the community health workers is of paramount importance for the success of a community based health service ${ }^{13,14}$. It was also learnt that ever talking to the CBRHAs about FP/ $\mathrm{RH}$ and satisfaction with CBRHA service were significantly better in successful areas. Interpersonal relations are important tools for communicating RH messages in communities where illiteracy is prevalent ${ }^{15}$. Another important issue is the involvement of the community in monitoring and evaluation of the program through community based structures such as village health committees (VHC). It was observed that more respondents in the successful areas witnessed the existence of a VHC that follows and evaluates the activities of the agents. This was also ascertained by the program coordinators who expressed that the functionality of $\mathrm{VHC}$ was better in the successful areas, albeit it was confessed that their functionality status is generally weak. The existence of strong VHC or other community-based structure has been demonstrated to be associated with the functionality of community health agents in Ethiopia and elsewhere ${ }^{14,16,17}$.

Based on our selection criteria, there is considerable attrition particularly in weak program areas. In addition, attrition of CBRHAs was mentioned as one of the major challenges in CBRHS. This may leave a big vacuum in the service delivery resulting in low service utilization rate and even collapse of the program. Many studies indicate that the success and sustainability of community based health programs largely depends on the program's ability to retain its most valuable resource, i.e., the community health agents or the volunteers ${ }^{17,18}$. This requires devising a sustainable means of motivating the agents. The fee-for-service (FFS) system established in this program was supposed to serve as remunerating mechanism but did not succeed as a result of multiple reasons, but mainly due to low interest by the community to pay for the services as they can get some services freely in the public clinics.

African Journal of Reproductive Health Vol. 11 No.2 August 2007 
Table 4: Summary of the FGD with Active CBRHAs

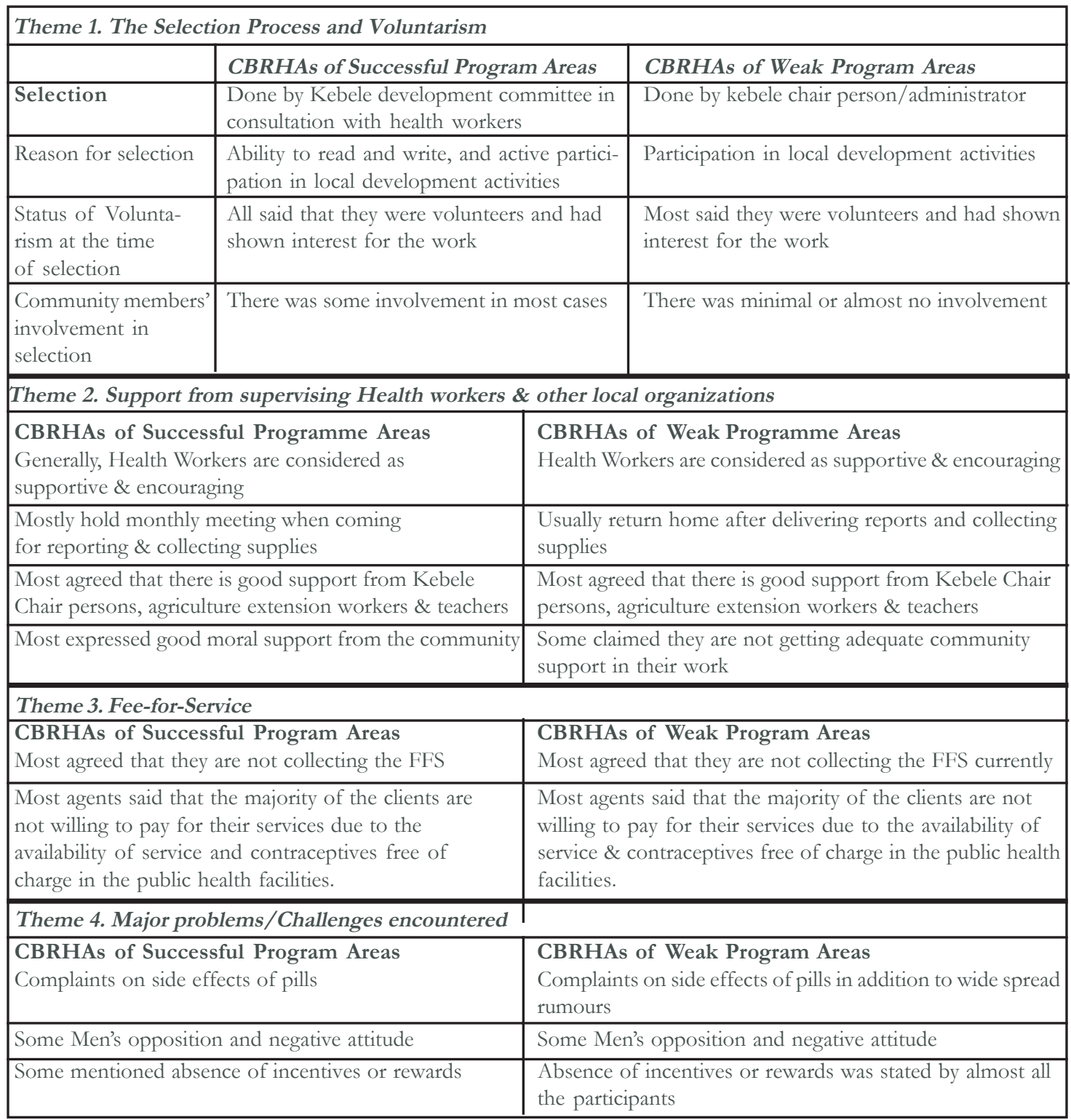

NB: Scoring:- The Model developed by East African Investment Securities commissioned by Pathfinder International with a view to tackling the issue in a systematic manner to assess the current situation and to take measures for enbancing the sustainability of RH/FP programs(11). The scoring for the factors were done as follows: 5= Very Highly favourable (VHF),4= Highly favourable (HF), 3=Favourable (F), 2=Unfavourable (UF), 1=Highly Unfavourable (HUF). After computing the results based on the above scores, the following benchmarks were used to assess the overall sustainability of the program:

4.5 - 5.0 A very bigh degree of sustainability already achieved

4.0 - 4.4 A bigh degree of sustainability already achieved but some areas need attention

3.0 - 3.9 A reasonable degree of sustainability already achieved but the Organization should systematically explore and implement ways of further enhancing the sustainability of its program.

Below 3.0 A low degree of sustainability. The Organization should develop \& implement a comprehensive sustainability program phased over the short, medium and long term.

African Journal of Reproductive Health Vol. 11 No.2 August, 2007 
In Kenya, Ferguson observed that charging FFS is unpopular among CBRHAs for keeping social status ${ }^{19}$. This indicates that there is a need to devise alternatives or diverse the mechanisms to keep agents working for a relatively longer period. The Program also has to effectively deal with false rumours and plan to diversify the types of contraceptives and work towards changing men's attitude for Reproductive Health services. Except the monthly meetings with CBRHAs from successful areas when they come to collect contraceptives, in practice there are no other ways of conducting supervision. In "weak" program areas, there does not seem to be any supervisory mechanism. Thus CBRHAs are unlikely to get the necessary support, motivation and leadership from the conventional health system.

Overall sustainability as assessed by program managers also revealed a low score $(<3.0)$, which according to the framework used for assessment means, an urgent action is needed. Sustainability in community-based distribution of family planning was also found to be a major problem in rural central Ethiopia in former program areas ${ }^{20}$.

In Conclusion, acceptance of CBRHAs, communication of the agents with community members, good community sensitisation and involvement, and sustained government and health staff support are important factors to consider for the betterment and continuity of the Program. Overall sustainability of the CBRHP appears very low and thus the concerned organizations should develop and implement a comprehensive sustainability program.

\section{Acknowledgement}

We are grateful for the financial assistance provided by the Austrian Embassy Development Cooperation. We acknowledge also Prof Kurt Weithaler, Melanie Wohlgennant, the Community Health Department of Addis Ababa University, and GTZ-PRHE for their valuable contribution and unreserved support.

\section{REFERENCES}

1. World Health Organization. The Global burden of reproductive ill-health. Progress in human reproduction research 1997; 42::1-8.

2. Türmen T. Operationalizing Reproductive Health: The Mother-Baby Package. Geneva, World Health Organization, 1995.

3. World Bank. World development Report 1993. Investing in Health. New York, Oxford University Press,1993.

4. Central Statistical Authority. Ethiopia, Demographic and Health survey. Addis Ababa, 2000.

5. UNAIDS/WHO. Epidemiological Fact sheet and sexually transmitted infections, Ethiopia. 2000 update.

6. FHD, MoH. Curriculum for the training of CBRHA, Ethiopia. Addis Ababa, 1997.

7. Gordon,G., Phiri F. Moving beyond the 'KAP GAP': A community based reproductive health program in eastern province, Zambia. International institute for environment and development, 2000.

8. Mitike G. Community based distribution of family planning as perceived by people in the reproductive age group, North and South. Gondar Zones, Ethiopia. Ethiop J Health Dev 2000; 14(1): 31-42.

9. Ethio-German Cooperation, Integrated family planning in Amhara Region, ZOPP 4 workshop report. Gondar, Ethiopia, Oct 1995.

10. Amhara National Regional State Health Bureau. Annual Health Activity Report. Bahir Dar, July 2000.

11. East Africa Investment Securities. Operational guideline for sustainability. COFAP/Pathfinder International, Addis Ababa, Feb 1999

12. Katz KR. Increasing access to family planning services in rural Mali through community-based distribution. Family planning perspectives 1998; 24(3): 104-110.

13. Oakley P. Community involvement in health development: An examination of the critical issues. World Health Organization, Geneva, 1989.

14. Rifkin BS. Community participation in $\mathrm{MCH} / \mathrm{FP}$ programs. WHO, Geneva, 1990.

15. Bruce J. Fundamental elements of quality of care and simple framework; Studies in family planning, 1990;21(2):61-69.

African Journal of Reproductive Health Vol. 11 No.2 August 2007 
Sustainability and factors affecting the success of community-based reproductive health programs in rural Northwest Ethiopia 79

16. Haile-Mariam D. Determinants of Community Health Agents functionality in Arsi Zone. (Thesis Work), Addis Ababa, May 1989.

17. Mohammed S. Determinants of Utilization of Community Health Agents in rural Communities. (Thesis Work), Addis Ababa, May 1989

18. From rhetoric to reality. Delivering reproductive health promises through integrated services. (1999); www.fhi.org/en/wsp/wspubs/rehtor.html.
19. Ferguson A. Motivating CBDs in Kenya, Kenya Family Health Project/MOH/GTZ Reproductive Health Project. Kenya/DFID/EEC Nairobi, 2001.

20. Genna S. Comparison of CBD, Non-CBD and Former CBD areas to assess effectiveness of Community Based Family Planning services. (Thesis). Addis Ababa University, Addis Ababa, 2000 . 